\title{
PROGRESS AND PROBLEMS IN REGULATION OF CONSUMER CREDIT*
}

\begin{abstract}
F. B. Hubachex $\dagger$
An article entitled "The Development of Regulatory Small Loan Laws" by this author in the 194I Winter issue of Law and Contemporary Problems dealt with the development of regulatory small loan laws during the period ending about 1940 . The purpose of the present article is to review subsequent developments in the same general field. It cannot cover precisely the same field because the periods 1916-1940 and 1940-r953 were basically different in significant respects. Some factors carried over but during the latter period the problems arising from the complexities of legitimate consumer lending were added to those of eliminating the illegal high-rate lender. The loan shark problem remains the crux but others have been created.

It is virtually impossible to draw a date line across this subject and state the then existing conditions accurately. Statutes and decisions can, of course, be dated but basic changes occur gradually. Events which seem mere incidents at the time emerge later as indications of a trend. To generalize with reasonable accuracy on this subject one can seldom refer to a specific date, but must use a longer period. Accordingly, "I940" and "I953" will be used in general statements herein as approximations only.

The loan shark evil is a modern, specialized aspect of the problem of usury. Whereas usury laws go back through the centuries, the loan shark did not begin to become an acute economic problem until the industrial revolution started in the eighteen seventies. It developed with the movement of population from rural to urban areas, the mechanization of industry, mass production, and dependence on paychecks. It is a concomitant of the wage system. Births, deaths, illnesses, unemployment, changes of residence, educational needs, misfortunes, or improvidence found families lacking reserves of food, clothing, shelter, or money and without land or skills by which they could sustain themselves. Borrowing or charity became their only means of emergency relief.

The bare costs of small installment loans to wage earners could not be covered by the percentage charges permitted under orthodox usury laws. Legitimate lenders could not supply the constantly growing demand at a loss. Charitable organizations

\footnotetext{
- The author acknowledges with appreciation the collaboration of Charles S. Kelly and Roger S. Barrett and the assistance of Charles $C$. Ulrich, all of the Chicago bar.

† A.B. 1915, LI.B. 1922, University of Minnesota. Member of the Illinois and Minnesota bars. General Counsel, Household Finance Corporation, since about r928; Chairman of Law Committec, American Association of Personal Finance Companies, for many years until 194r; Chairman of Committee on Law Bulletin, Law Forum of National Consumer Finance Association. Author, AnNotations on Small Loan laws (Russeli Sage foundation, 1938).
} 
could scarcely begin to cope with it. The borrowers lacked business experience and the ability to enforce their meager legal remedies. Their need made them desperate. Their only source of credit or loans was the money bootlegger, whose extortionate charges and harsh collection methods earned the term "loan shark."

These economic and social changes had been gradual and only a few realized that they called for drastic changes in the usury laws. Lawmakers clung to the age-old concept that charging over 6 per cent was malum in se, and hence the sorry succession of efforts to put out the economic fire by statutory prohibitions and penalties. Inevitably the conflagration raged hotter.

Eventually, starting in the eighteen nineties, a few industrialized states were forced to a more realistic attitude. They enacted experimental laws which timidly, or unconsciously, recognized that wage earners must borrow when the thin gap between wages and necessities closed. Finally, in 1907, the Russell Sage Foundation entered the lists as a champion of the wage earner, and combating the loan shark then began in earnest. By I9I6 the Uniform Small Loan Law $^{1}$ had been drafted as the weapon for that purpose.

This law has virtually eliminated the loan shark wherever it has been enacted in full. It has done so by permitting a regulated, commercial, competitive source of consumer loans to operate at much lower than the loan shark's rates though substantially higher than ordinary usury limits. By I940 there was wide public acceptance of this law and the operations under it. The most serious opposition to its maintenance and extension came from loan sharks operating in unregulated states, licensees who wished to capture additional profits, and other lenders whose operations would be affected.

That was the situation when the earlier article was written. What are the most important subsequent developments? What influences have been at work and what changes have they produced?

Because the important developments during this period include legal, economic, and social changes which affect business and government and the daily lives of our people, it is impossible to review them chronologically, by cause and effect, or on any other single plan. There are, however, certain crisscrossing lines of cleavage which suggest the following headings under which appropriate material may be grouped:

\footnotetext{
${ }^{1}$ Terminology. Because consumer loans are small in comparison with business or productive loans, the former came to be known as "small loans," and the laws regulating lenders making them came to be known as "small loan laws." These terms are now inappropriate as they do not refer to the distinguishing characteristics of consumer loans-that they are made to finance consumer needs and are repayable in installments. "Consumer loans" and "consumer finance" are being used increasingly to describe such loans. The broader term "consumer credit" is universally used to mean both consumer loan and sale credit, the latter being extended as an incident of a sale transaction. Because of the variety of laws regulating the making of consumer loans, however, the laws providing the primary regulation are still called "small loan laws" when necessary to distinguish them from other consumer loan laws. Lenders doing business under small loan laws are usually the only group which is licensed, and hence they are often called "licensed lenders" or "licensees."
} 

I. Influence of Russell Sage Foundation.
II. Small loan legislation-recapitulation.
III. Newer types of consumer lenders-their regulation.
IV. Larger loans and smaller profit margins.
V. Convenience and advantage provision.
VI. Credit life and disability insurance.
VII. Special constitutional problems.
VIII. Trend toward a code.
IX. Regulation W-economic considerations.
$X$. The present situation.

Influence of Russell Sage Foundation

To the Russell Sage Foundation, an endowed philanthropic agency, must be credited the sound statutory foundation of the small loan (consumer finance) business. ${ }^{2}$ The Foundation began its work in the remedial loan field in $1907 .{ }^{3}$ Its studies dislosed a vital need for small loans among wage earners which was not being met by orthodox lenders but rather by loan sharks who cruelly exploited their victims. One result was the drafting in rgr6 of the model Uniform Small Loan Law which has been the guide for all effective subsequent small loan legislation.*

The following over-all, inclusive, maximum monthly rates, computed strictly on the unpaid principal balances of money actually advanced to the borrower, without discounting or compounding, are allowed by existing small loan laws on all or a portion of the loan balance: $3-1 / 2$ per cent in 7 states, 3 per cent in 19 states, $2-1 / 2$ per cent in 6 states, 2 per cent in one state, and slightly over 2 per cent in 2 states; and one state provides for interest and fees.

After releasing its first draft of USLL, the Foundation continued to observe and study consumer finance and the effects of laws regulating its various aspects.

\footnotetext{
2 For development of laws regulating the small loan (consumer finance) business, see the following, all published by the Russell Sage Foundation (New York): Robinson and Nugent, Reguration of THE Smali loan Business (1935); Gallert, Hilborn and May, Small loan Legislation (1932); Hubachex, Annotatrons on Small Loan Laws (1938); and GlenN, Brandt and Andrevis, Russell Sage FOUNDATTON I907-1946 (1947).

${ }^{3}$ GlenN, BrandT AND ANDrews, id. at 65.

"The principal features of the Uniform Small Loan Law have been summarized: "( $(1)$ licensing . . . of lenders; (2) special authorization to licensees ... to charge a maximum monthly per cent rate on unpaid balances, which is substantially greater than the general usury maximum; (3) prohibition against extra charges; (4) detailed regulations as to the conduct of business by licensees; (5) prohibitions against evasions by licensees and non-licensees; (6) supervision by a state official; (7) criminal and civil penalties for violations; (8) maximum loan size to which the act applies, originally $\$ 300$ but usually $\$ 500$ or more in recent legislation; (9) exemption of banks, industrial banks, building or savings and loan associations, credit unions, and pawnbrokers. The regulations as to the conduct of business are designed to protect small borrowers from the fraud and oppression possible because of their inadequate bargaining position. These include, for example, a prohibition against misleading advertising and requirements that the lender give the borrower a statement of his loan transaction and a receipt for cach payment. Unlicensed lenders, unless expressly exempted, are specifically limited to the maximum provided by the usury law and are subject to severe penalties for exceeding this maximum either directly or by subterfuge." Roger S. Barkett, Compilation of Consumer Finance laws xiv (Nat. Consumer Fin. Ass'n, 1952).
} 
Its published material and presentations at hearings gained the support of legislators, public officials, Better Business Bureaus, Legal Aid Societies, labor unions, philanthropic organizations, and other public spirited groups, for legislation which it recommended. Seven drafts of the Foundation's uniform bill were published, the last in 1942. The basic principles of the first draft were continued in all later drafts. Changes merely improved the law to meet changing conditions. ${ }^{5}$

By $x 942$ the Russell Sage Foundation had come to believe that its work in this field was largely completed. The principles of sound regulation and rate statement had been tested, proved effective, and accepted. Thereafter the Foundation diminished its activity. The untimely death of Dr. Rolf Nugent ${ }^{\theta}$ shortly after World War II ended its active participation, though the influence of its pioneer work of course continues to be a vital factor.

No like agency has emerged to assume the role of protector of the consumer debtor. Without the leadership of a strong and universally respected agency, dedicated to the public good, the movement for firm, consistent regulation of all consumer creditors has faltered. In many cases, fundamental differences in the statutory treatment of different types of lending institutions which are actually distinguished from each other only by their names and business histories, have been perpetuated instead of being broken down. A few states have recently abandoned some of the basic concepts of the Uniform Small Loan Law.

Studies of small loan and sales finance problems are being continued by professors and research institutions. This promotes an understanding of consumer credit and provides a constructive influence on regulatory legislation. The efforts, however, are uncoordinated and insufficiently publicized. Although the National Consumer Finance Association and its Law Forum have published much useful material, ${ }^{7}$ there has been no impartial headquarters for the dissemination of findings or publications.

Since 1942 there has been moderate need for revision of the Uniform Small Loan Law. To meet this need the National Consumer Finance Association in 1948 drafted and published a Model Consumer Finance Act which preserves the basic features of the Uniform Small Loan Law. It differs in important details and it has been considerably simplified, continuing a process started by the Foundation. It is an endorsement and perpetuation of the principles of the Uniform Small Loan Law.

\footnotetext{
'For differences between the drafts, see historical discussion following each annotated section in Hubacheк, op. cit. supra note 2; Foreword by Nugent, id. at vii; Historical Development by Nugent, id. at 193 .

${ }^{\circ}$ Dr. Nugent was the last Director, Department of Consumer Credit Studies, Russell Sage Foundation, succeeding Mr. Leon Henderson.

${ }^{7}$ Barrett, op. cit. supta note 4; Barrett and Ulrich, Index to Legal Literature on Regulation of Consumer Installment Lending and on Usury Laws (1940); BarretT and Ulrich, Supplement to Annotations on Small loan Laws (mimeographed, 1948); Haller, Consumer Installment Loans (bibliography, 1945); Survey of Soldiers' and Sallors' Civil Relief Act in Relation to Consumer Credit Obligations (1950); Operating Instructions for Bankruptcy (I951); Federal Laws and Their Application to the Consumer Finance Business (mimeographed, 1952); Consumer Finance Law Bulletin, published quarterly since June 1947; Model Consumer Finance Act (1948).
} 
II

\section{Small Loan Legislation-Recapitulation}

When "Combating the Loan Shark" was written, 27 states had effective small loan laws resembling one or more drafts of the USLL, three states had partially effective small loan laws, and five had laws resembling the USLL which were ineffective because the permitted rates were too low. ${ }^{8}$ Since then six additional states (Idaho, Nevada, Oklahoma, South Dakota, Washington, and Wyoming) have enacted small loan laws either patterned on or strongly influenced by the USLL, although the laws of all these states except Idaho and Washington are deficient in important respects. The $3^{6}$ states now having effective or partially effective small loan laws include most of the large industrial states and have about 79 per cent of the United States population against about 74 per cent in $19400^{\circ}$ Under these laws, small loans totaling $\$ 2,67 x, 000,000^{10}$ were made in 1952 .

Late in 1939 the Canadian Parliament enacted a small loan law applicable throughout the Dominion, based on the USLL principles, with a $\$ 500$ loan limit, effective January $\mathrm{x}, 1940.11$

In addition to the extension of regulation to new states, progress has been made since $194^{\circ}$ in the improvement of then existing laws. The Uniform Small Loan Law was substantially strengthened in the fifth draft (1932) by the addition of broad discretionary powers. The most important were discretionary licensing on the basis of various criteria, power to prohibit dual business operations, and power to adopt rules and regulations. These provisions have since been adopted in many states, either as a part of new small loan laws or by amendment of existing laws. Much of this progress has occurred since 1940. The number of small loan laws having the convenience and advantage licensing restriction increased from 13 to $23 ;^{12}$ the number delegating rule making power increased from 15 to $30 ; ;^{13}$ and the number having a dual business restriction increased from 15 to $24 .{ }^{14}$

That is the score of principal accomplishments since 1940 in extending the frontiers against loan sharks and improving the situation in previously regulated territory. How much remains to be done?

${ }^{8}$ Hubachek, The Development of Regulatory Small Loan Laws, 8 Law \& Contemp. Prop. 108, 123 (I94I). Effective laws: Ariz., Cal., Conn., Fla., Ill., Ind., Iowa, Ky., La., Me., Md., Mass., Mich., Minn., Mo., N.H., N.J., N.Y., Ohio, Ore., Pa., R.I., Utah, Vt., Va., W. Va., Wis. Partially effective laws: Colo., Neb., N.M. Ineffective laws: Ala., Ark., D.C., Ga., Tenn. For citations to and reprints of small loan, usury, and related laws, as of I952, see BARRETr, op. cit. supra note 4.

${ }^{\circ}$ U. S. Census of Population (ig5o); CuRrent Population Reports, Population Estimates (Bur. of Census, U. S. Dept. of Commerce, March 24, r953).

1039 Fed. Res. Bull. 276 (March, 1953). ${ }_{11} 3$ Geo. VI, c. 23, c. 30, 512 (1939).

${ }^{2}$ Having restriction in 1940: Conn., Ill., Ky., Mich., Minn., N. J., N. Y., Pa., R.I., Utah (in banking law), Vt., W. Va., Wis. Subsequently adopting restriction: Idaho, La., Md., Neb., Nev., N.M., Ohio, Okla., Ore., Wash.

${ }^{13}$ Rule-making in 1940: Cal., Conn., Ill., Ind., Ky., Mass., Mich., Minn., N.J., N.Y., R.I., Utah, Vt., W. Va., Wis. Subsequently authorizing rule-making: Colo., Fla., Idaho, Iowa, Mo., Neb., Nev., N.M., Ohio, Okla., Ore., Pa., S.D., Va., Wash.

1" Having restriction in 1940: Cal., Conn., Ill., Iowa, Ky., Mich., Minn., N.J., N.Y., Pa., R.I., Utah, Vt., W. Va., Wis. Subsequently adopting restriction: Idaho, La., Neb., Nev., N.M., Ohio, Okla., Va., Wash. 
Loan sharks still operate to varying extents in the District of Columbia, Alabama, Arkansas, Delaware, Georgia, Kansas, Mississippi, Montana, North Carolina, North Dakota, South Carolina, Tennessee, and Texas-all because of the lack of effective small loan laws. Where these unregulated areas are bordered by states having modern small loan laws, the loan shark situation is improved by the access of consumers to legitimate loan facilities.

Loan sharks also operate to a relatively minor extent in states having deficient or only partially effective small loan laws. The task there is to modernize such laws.

The I953 loan sharks are a hardy, agile lot, conditioned by having survived half a century of efforts to eliminate them. As always they thrive best in the centers of population where dependence on wages is greatest. But today industry flourishes in small towns and this is being accelerated by the national policy to disperse large plants. Eight of the twelves states remaining unregulated are in the south where industrialization has been recent and high-rate illegal lenders are most strongly entrenched.

There are indications pointing toward the extension of remedial legislation, however. The increased loan shark activity that has come with industrialization has aroused new public interest in the problem. Rumblings of public discontent with unregulated lenders are heard in all the unregulated states. In Arkansas, the unconstitutionality of a I95I loan law and the futile attempt in 1952 to amend the constitution were widely publicized and may have laid the ground work for constructive action. In Texas, bar association committees and many others are earnestly striving for law enforcement and a constitutional amendment. In Kansas, the Attorney General has recently instituted injunction and receivership proceedings against numerous loan shark offices. ${ }^{15}$ All these situations will, of course, be liquidated eventually.

\section{III}

\section{Newer Types of Consumer Lenders-Their Regulation}

Before IgI7 loan sharks were virtually the sole commercial source of loans to finance family needs. The principal objective of the original small loan laws therefore was to eliminate loan sharks and create a regulated, comparatively low cost source of credit to replace them. Other lenders, notably banks, were specifically exempted from the privileges, regulations, and penalties of the small loan law. Sales finance transactions have usually been held not to be loans and thus sales finance companies were, in effect, exempted. ${ }^{16}$ The operations of Morris Plan

${ }^{16}$ Kansas City Times, Aug. 6, 1953, p. I; Kansas City Star, Aug. 5, x953, p. r.

${ }^{10}$ See Cady L. Daniels v. Fenton, 97 Colo. 409, 50 P. 2d 62 (1935); Black v. Contract Purchase Corp., 327 Mich. 636, 42 N. W. 2d 768 (I950); People v. Morse, 270 Ill. App. 207 (1933); Porter v. Stolkin, I0I Ind. App. 705, 200 N. E. 74 (I936); General Motors Acceptance Corp. v. Swain, 176 So. 636 (La. App. 1937). Such transactions are occasionally held to be loans under the usury laws. E.g., Hare v. General Contract Purchase Corp., 220 Ark. 60I, 249 S. W. $2 d 973$ (I952); Schuck v. Murdock Acceptance Corp., 220 Ark. 56, 247 S. W. 2d I (x952); Milo Theater Corp. v. National 
lenders (now called industrial loan companies) created minor problems but they were usually exempted. Credit unions, pawnbrokers, and sometimes remedial loan associations, were also exempted because special statutory regulations were otherwise provided for them.

This centering of legislative attention on loan sharks and licensed lenders worked out very well while other types of lenders did not make small loans in substantial volume. The field was circumscribed by the actual practices and the law covered the entire field. By the late nineteen thirties banks and industrial loan companies, however, were making a large volume of small loans. During World War II when consumers' durable goods were not available, the sales finance companies also entered the consumer loan business. As the participation of these three comparatively unregulated groups expanded in this field, their operations increasingly overlapped those of licensed lenders. ${ }^{17}$

Most of the new consumer lenders were usually reasonable in their average charges although their methods of operation produced a wide range of rates of charge, very high under certain circumstances.

Because they were exempted from the small loan law and not licensed under it, they remained subject to the general usury laws which their charges violated. To camouflage this and for competitive reasons they elected to conceal their true rates. and amounts of charges by discounting an amount of interest computed on the original face of paper repayable in installments, by charging fees and fines, and by failing to give full rebates on prepayment. This behavior was another result of the law lagging behind economic changes.

These conditions led to piecemeal legislative action which, unfortunately, lacked any consistent plan or philosophy. Because this did not develop until toward the end of the Russell Sage Foundation's activity, it did not perfect model bills applicable to the new types of consumer lenders. The Foundation did propose an experimental personal loan bill for banks which was rejected by the banks as too onerous, although Nebraska enacted a modified version. ${ }^{18}$ A similar effort for a model sales finance act also failed for the same reason. The statutory regulation which subsequently developed was the result of uncoordinated legislative action based on the fortuitous circumstances surrounding each separate enactment.

Banks. New York in 1936 enacted a fairly comprehensive regulatory law applicable to the personal loan departments of banks. ${ }^{19}$ Iowa, Nebraska, New Jersey, and Pennsylvania later enacted laws providing some degree of regulation for the

Theater Supply, 7I Idaho 435, 233 P. 2d 425 (I95I); White v. Disher, 232 N. C. 260, 59 S. E. 2 d 798 (I950); Nazarian v. Lincoln Finance Corp., 77 R. I. 497, 78 A. 2d 7 (I95I); Associates Inv. Co. v. Sosa, 24I S. W. 2d 703 (Tex. Civ. App. 195I); G.F.C. Corp. v. Williams, 23I S.W. 2d 565 (Tex. Civ. App. I950); Gifford v. State, 229 S. W. $2 \mathrm{~d} 949$ (Tex Civ. App. 1950). See Berger, Usury in Instalment Sales, 2 LAw \& Contemp. Prob. 148 (x935); Note, Are Installment Plans Usurious?; 36 Minn. L. Rev. 744 (1952).

17 Nugent, Consumer Credit and Economic Stability ito (Russeld Sage Foundation, 1939).

${ }^{18}$ Neb. Rev. Stat. $\$ \$ 8-80$ I to 8-81 4 (r943), Cum. Supp. \$8-812 (195I). For reception of model bill, see 2 GLENN, BrANDT AND ANDREws, op. cit. supra note 2, at 544 .

${ }^{10}$ N. Y. Laws 1936, c. $882 ;$ N. Y. Banking Law $\$ 108$, subd. 2 (a). 
consumer loan operations of banks. The initial bank legislation tended merely to set maximum amounts and to validate discounts, fees, delinquency and collection charges, and other methods of operation without providing regulations in the borrowers' interest. The seriousness of these omissions remains to be appraised. The strict regulations of the small loan law are scarcely needed in the case of banks, but some degree of regulation is essential. Their consumer loans are in larger average amounts, a fact which implies less necessitous borrowers. The responsible nature of the average bank affords a certain protection to the borrower, although it may also tend to lull him.

Twenty states now have laws authorizing banks to make charges on installment loans exceeding the general usury law maxima. ${ }^{20}$ Four additional states (Connecticut, Massachusetts, Maine, and Rhode Island) have such laws but they are restricted to savings banks and savings departments of commercial banks. In 23 states, including the above 4 , banks may make installment loans without special authorization, either because they are not subject to interest restriction, ${ }^{21}$ or the usury law permits a comparatively high rate of interest, ${ }^{22}$ or other laws permit greater charges on installment loans than the general usury maxima. ${ }^{23}$

Industrial loan companies. Their early operations were another effort to supply a demand which antiquated usury laws at that time made it impossible to supply on a legal basis. Industrial loan companies originally relied on the sale of investment certificates as a device to conceal the rates of charge on loans. By requiring the borrower to purchase an investment certificate on the installment plan and by crediting his payments to the purchase instead of to the loan, the true rate of charge was made less apparent. They also used expense charges, delinquency fines, and other devices to eke out a commercially practicable rate of charge. ${ }^{24}$ Their average charges obtained by the discount and fee method only, aggregated about 17 per cent per year, but these were greatly increased in the average case by other means. ${ }^{25}$

These companies eventually obtained enabling laws in 29 states $^{26^{\circ}}$ and Hawaii, most of which contain virtually no provisions protecting the borrower. The more recent laws and amendments provide some protection in the form of more candid authorization of rates of charge, ${ }^{27}$ requirement of a refund on prepayment when

${ }^{20}$ Del. (1935), Fla. (194x), Ind. (195I), Iowa (1945), Ky. (1946), Mich. (1929), Minn. (1945), Miss. (1940), Neb. (1943), N. J. (1936), N. Y. (1936), N. C. (1937), Ohio (1935), Ore. (1953), Pa. (1945), S.D. (1953), Tex. (1943), Va. (1938), W. Va. (1943), Wis. (1943). The Del., Ind., and S. D. laws are not restricted to banks. For citations to bank installment loan laws, as of 1952, see BARRETT, op. cit. supra note 4 .

a1 Cal., Colo., Conn., La. (discounted interest not restricted by usury law), Me., N. H.

${ }^{23}$ Ark., Kan., Mass., Mont., Nev., N.M., Okla., R.I., Utah, Wash.

${ }^{23}$ Ala., Ariz., Ga., Md. (Industrial Finance Law), Mo. (general consumer loan law), S. C., Wyo.

${ }^{24}$ See Robinson and Nugent, op. cit. supra note 2, at 91; Saulnier, Industrial Banking Companies and Their Credit Practices 43 (Nat. Bur. of Econ. Res., 1940); Industrial Banking Legal Digest 312 (Consumer Banking Institute, 1945).

${ }^{20}$ New Morris Plan, Time, Nov. 13, I933, p. 47, col. I. See also Saulnier, id. at 92.

${ }^{20}$ Ark., Cal., Colo., Conn., Fla., Ga., Ind., Ky., Me., Md., Mass., Mich., Minn., Mont., Neb., N.Y., N.C., Ohio, Ore., Pa. R.I., S.C., Tenn., Tex., Utah, Va., Wash., W. Va., Wis. For citations to these laws and reprints of some of them, as of I952, see BARRETT, Op. cit. stupra note 4.

${ }^{27}$ Cal. Financtal COde ANN. \$\$18655, 18656 (I95I); IND. Stat. ANn. \$I8-3107 (Burns, 1950); Neb. Rev. Stat. \$8-40I (1943). 
charges are taken in advance, and restriction against repetition of fee charges. Among such laws are the Maryland Industrial Finance $\mathrm{Law}^{28}$ (1945) with a $\$ 1,500$ maximum, the Pennsylvania Consumer Discount Company Act (I937) with a $\$ 2,000$ maximum, amended in $1947 ;^{29}$ an old Wisconsin statute with a $\$ 2,000$ maximum, amended in $1947 ;^{30}$ and the Indiana Industrial Loan and Investment Act, as amended. $^{31}$ These four laws are used by small loan licensees to make loans in amounts larger and at rates somewhat lower than those permitted by small loan laws.

Sales Finance Companies. Installment vendors and the sales finance companies which purchase their sale contracts at a discount, operate on the legal theory that such transactions are not loans and hence are not subject to the usury and small loan laws. These transactions were virtually unregulated in r940 except in Indiana, Massachusetts, and Wisconsin. ${ }^{32}$ With the extension of sales financing to inexpensive articles, soft goods, and luxuries, the abuses inevitably multiplied and called for regulation to protect the buyers. By 1953 , I6 states and Hawaii had imposed varying degrees of regulation on sales financing. ${ }^{33}$ The only common feature of these laws is the requirement that the terms and related information of sales contracts be disclosed-an essential requirement in any consumer credit transaction. This is the sole requirement found in the Massachusetts, New York, and Virginia laws. Most of such laws also provide for licensing of sales finance companies and sometimes dealers, and require refunds of unearned charges on prepayment. ${ }^{34}$ Some fix maximum finance charges.

Sales finance companies have expanded into the small loan field. This can legally be done in most states only by obtaining a license under the applicable small loan or other consumer loan law. The Oregon Motor Vehicle Finance $\mathrm{Act}^{35}$ regu- $^{2}$ lates lending on automobile security. The question at once arises whether conducting the small loan and sales financing businesses together will "facilitate evasion of the small loan law" and require denial of the license. The Nebraska small loan law was recently amended to permit the small loan business to be operated in conjunction with the sales finance and insurance businesses, ${ }^{36}$ a questionable step.

${ }^{28} \mathrm{Md}$. Code ANn. Art. IT, $\$ \$ 163-205$ (1951).

10 PA. Stat. ANn. tit. 7, \$\$761-r to 761-19 (1939 \& Supp.).

${ }^{80}$ WIS. STAT. \$II5.09 (195I).

${ }^{31}$ IND. StAT. ANN. \$\$I8-3I0I to I8-3125 (Burns, 1950 \& Supp.).

s2 Ind. Laws 1935, c. 231; Mass. Acts 1939, c. 509; Wis. Laws 1935, c. 474.

${ }^{38}$ States marked with asterisk restricted to automobile financing: Cal." (1945), Colo.* (1951), Conn. (1947), Hawaii (1941), Ind. (1935), Me** (1939), Md. (1941), Mass. (1937), Mich.* (1939, r950), Nev.* (1953), N.J. (1948), N.Y. (1941), Ohio (x949), Pa.* (1947), Utah (1953), Va. (1944), Wis.* (1935). For citations to and reprints of sales finance laws, as of I952, see BARRETT, op. cit. supra note 4.

${ }^{84}$ For a classification and discussion of provisions of sales finance laws, see Mors, State Regulation of Retail Instalment Financing-Progress and Problems, 23 J. of Bus. U. of CHr. 199 (1950), 24 J. of Bus. U. of CHr. 43 (1951); Donaldson, An Analysis of Retail Installment Sales Legisldtion, ig Riockx MT. L. REv. 135 (1947); Regulation of Retail Installment Sales: New Statute in Ohio, 63 Harv. L. REv. 874 (1950).

85 ORE. COMP. LAwS ANN. $\$ 42-401$ to $42-426$ (1940 \& Supp. 1943).

${ }^{36}$ Neb. Laws 1953 , L.B. 280. 
The possibility of abuses arising out of the conduct of the two businesses together has been suggested in several cases. A licensed Ohio lender purchased an automobile installment sale contract and refinanced it by a small loan without refunding the unearned finance charge, and the court ruled against the lender. ${ }^{37}$ In California a licensed lender made a loan partly to finance the purchase of a truck which the lender sold to the borrower under a mortgage; the lender was held to have violated the Motor Vehicle Installment Sales Act. ${ }^{38}$ A California legislative committee found that sales finance companies were refinancing sales contracts under the small loan law without refunding unearned sales finance charges, and that this practice resulted in misdirected criticism of the small loan law. ${ }^{39}$

Defects in regulation of consumer lenders. The continuing hodge-podge of differing rates, methods of rate statement, regulations, and administrative systems in the regulated states presents a most serious problem and a challenging opportunity in the consumer credit field. ${ }^{40}$ The great need to integrate and harmonize these laws is illustrated in states where there is a weak companion law to a strong small loan law. There the companion act provides a ready means of avoiding the restrictions of the small loan law.

Oregon and Utah have adequate small loan laws but their industrial loan laws permit discount and fee charges yielding more than 2 per cent a month and, under some circumstances, more than 3 per cent a month, ${ }^{402}$ with meager protection of the borrower. Lenders may choose the law under which they will operate. South Dakota in I953 enacted a small loan law and also a discount and fee loan law; the latter, though intended primarily for banks, is already being used by other lenders to avoid the small loan law. In Wisconsin effective regulation of consumer loans was handicapped by sections of the usury act which permitted sufficient charges for the larger loans, under which both licensed and unlicensed lenders made loans. In I947 the sections were revised ${ }^{41}$ and surrounded by regulatory safeguards, including restrictions on the refinancing of loans under a different law than that under which they were made.

In several states licensees under the small loan law also make loans exceeding $\$ 300$ under other laws which provide inadequate regulation and do not mesh with the small loan law. Massachusetts licensees charge more for the larger loans which are subject only to the Tender $\mathrm{Act}^{42}$ than for loans of $\$ 300$ or less under the small

\footnotetext{
${ }^{37}$ Porter v. Interstate Securities Co., 37 Ohio Op. 194, 79 N. E. 2 d 155 (Com. Pl. 1948).

${ }^{38}$ Carter v. Seaboard Finance Co., 33 Cal. 2d 564, 203 P. $2 d 758$ (I949), construing Cal. Gen. Laws, Act 5825 (Deering, 1944) and Civil Code, $\$ 2981,2982$ (Deering, 1949).

${ }^{30}$ Report of Joint Legislattve Commitee on Lending Transactions 9 (1949).

${ }^{10}$ Bogert, The Future of Small Loan Legislation, I2 U. of Crr. L. Rev. I (r944); Hubachek, The Drift Totuard A Consumer Credit Code, I6 U. of Chr. L. Rev. 609 (I949).

son The Supreme Court of Utah recently stated that the discounting of interest at I per cent per month and of a 2 per cent fee from a two-year intallment note as authorized by the Industrial Loan Act resulted in an interest rate of 37 per cent per annum. Seaboard Finance Co. v. Wahlen, 260 P. $2 \mathrm{~d} 556$ (1953).

${ }^{41}$ Wis. Laws 1947 , c. 462 , Wis. STAт. $\$ \$ 115.07$, I15.09 (I95I).

12 ANN. LAws Mass., c. I40, $\$ \$ 90-95$ (1949).
} 
loan law, and induce borrowers to take more than $\$ 300$ to avoid the small loan law. Similar situations were corrected by legislation in California (1949) ${ }^{43}$ and Maine (r953), ${ }^{44}$ but still exist in Louisiana and New Hampshire. The same state of affairs in Colorado was partially corrected under a decision ${ }^{45}$ which imposed some regulation above $\$ 300$ by reinstating a I9I3 loan law which was thought to have been repealed.

\section{IV}

\section{Larger Loans and Smalier Profit Margins}

On the basis of the studies completed in IgI6, the first small loan laws were drafted to apply only to loans of $\$ 300$ and less. The emergency needs of an average wage earner were then met by $\$ 300$. In I922-23 the average loan was "somewhere between $\$$ II $3_{3}$ and $\$$ I27."4B The $\$ 300$ loan limit was fixed by most small loan laws which became effective before I940, with the noteworthy exceptions of the early Ohio and Nebraska acts which had no size limit. In the seventh draft (1942) the Foundation stated that a maximum of $\$ 400$ or $\$ 500$ would be warranted in some states. ${ }^{47}$

It became apparent shortly after I940 that the $\$ 300$ loan limit had become insufficient on a nation-wide basis and that failure to increase it was creating serious mischiefs in the regulatory plan. Individuals whose needs had formerly been satisfied with $\$ 300$ now required $\$ 500$ to $\$ 750$ for the same purposes. The original $\$ 50$ borrower might now need $\$ 350$. Wage earners were obtaining two, three, or more loans from different licensees. As rates generally decrease with the increasing size of the loan, borrowers were usually paying higher rates for their money under two or more loan contracts for smaller amounts. Because the smaller loans cost the lender more per dollar lent, dividing up an indebtedness into smaller parts caused an uneconomic waste.

Between 1940 and 195 I the average size of small loans nearly doubled. In Illinois this increase was from $\$ 133$ to $\$ 25^{2}$ and the average loan balance increased from $\$$ Iro to $\$ 209.48$ The maximum loan under the Illinois law was increased from $\$ 300$ to $\$ 500$ in $1947^{49}$

A loan limit exceeding $\$ 300$ has been adopted in I7 states since 1940 , including 8 states that replaced an effective $\$ 300$ limit. ${ }^{50}$ A $\$ 500$ limit may now be outmoded;

\& Cal. Stat. \& CODE AMdTs. 1949, cc. 595, 1033, 1034.

"Me. Acts 1953, c. 215.

${ }^{45}$ Sullivan v. Siegal, 125 Colo. 544, 245 P. 2d 860 (1952).

- Robinson and Stearns, Ten Thousand Small Lonns it7 (Russell Sage Foundation, 1930).

- Seventh Draft of USLL, n. $\mathrm{I}$, reprinted in BARRETT, op. cit. supra note 4 , at 684 .

${ }^{48}$ Analysis of Reports Filed by Personal Finance Companies [for] 1941, p. 7; [same for] I95I, p. 7. Issued by Div. of Small Loans, Dept. of Ins., Ill.

${ }^{\circ}$ Ill. Laws 1947 , p. Ir52.

${ }^{10} \$ 500$ : Conn.*, Ill.*, Ind.*, Mich.*, N.J.", N.M., N.Y.*, Wash.; \$600: Pa."; \$rooo: Neb., Ohio, Wyo.; \$1,500: Nev.*; \$2,500: Me., S.D.; \$5,000: Cal.; no maximum: Mo. States marked with asterisk had effective $\$ 300$ limit. Missouri has $\$ 400$ nominal limit but permits larger loans. The original Nebraska and Ohio laws did not have a maximum loan size. The Washington and South Dakota laws originated with their current larger loan sizes. The California, Maine, and New Mexico laws had a nominal 
since 1947,7 states have adopted even larger limits. ${ }^{51}$ In Io of the I9 states where the small loan limit remains at $\$ 300$, licensees now can, and generally do, make larger loans under other laws. ${ }^{52}$

Paralleling the decrease of dollar purchasing power as a cause of the increased size of consumer loans, there has been an expansion of the reasons for borrowing. The period under review has been one of high employment, increasing wages, improved living standards, and a steady increase in the articles believed by consumers to be essentials. Yesterday's luxuries are today's needs. The wage earner now requires goods and services of a higher and more expensive order than ever before.

Wants have tended to be added to needs as an actuating force of consumer borrowing. Much sales finance paper is later refinanced by small loans. Insistent desire is only a little less potent than need, in reducing a borrower's caution and his bargaining power. ${ }^{53}$ Hence it is almost as desirable socially for the law to equalize the bargaining power of the wage earner borrowing to fulfill a want as to meet a necessity. In either case the wage earner would be a likely loan shark victim unless a regulated source of credit is provided. History has proved that the state must foster a regulated source of credit for necessitous persons, whether or not it is also patronized by those of lesser need.

The same economic changes which forced larger loans have greatly increased the costs of lending. In contrast, maximum rates of charge for larger loans (and in some states for the smaller loans) have decreased. ${ }^{54}$ This squeeze of profit margins has been only partially offset by improved operating efficiency and by the increase in dollar income per loan resulting from the larger amounts lent. The result has been a progressively lower rate of net return since $1940 .{ }^{55}$

The changes which have occurred are illustrated by the statistics in Table $\mathrm{I}^{56}$ for Iowa and Virginia, which have a maximum $\$ 300$ loan, for Illinois and New York which have increased their maximum from $\$ 300$ to $\$ 500$ since r940, for Ohio which has permitted larger loans since before 1940 , and for Wisconsin which has a $\$ 300$ maximum but has permitted licensees to make larger loans under another law since before 1940 .

maximum loan size of $\$ 300$ but licensees made larger loans on varying bases. The original Wyoming maximum loan size was $\$ 150$, but licensees made larger loans under a discount law.

${ }^{61}$ Cal., Me., Mo., Nev., Pa., S.D., Wyo.

${ }^{62}$ Ariz., Colo., La., Md., Mass., N.H., Ore., R.I., Utah, Wis. $\quad{ }^{63}$ Hubachek, supra note 8, at 130.

64 E.g., for loans of $\$ 300$ or less there were the following reductions in maximum rates: Md., from $3-1 / 2$ to 3 per cent (x943); Mass., statutory ceiling on Commissioner's rate-fixing power reduced from 3 per cent to marginal 2 per cent (1946); N.Y., from 3 per cent on first $\$ 150$ and 2 per cent on remainder to $2-1 / 2$ per cent on first $\$$ roo and 2 per cent on remainder (I94I); Va., from $3-1 / 2$ to 2 per cent (I942), subsequently increased to $2-1 / 2$ per cent (I944). Ohio changed from 3 per cent on the first $\$ 300$ plus a $\$ \mathrm{x}$ fee on loans of $\$ 50$ or less to 3 per cent on the first $\$ 150$ and 2 per cent on the next $\$ 150$ (1943).

"Thelps, Consumer Finance Company Charges, I6 Journal of Marketing 397, 406 (I952).

${ }^{\text {EB }}$ Compiled and computed from the published state reports of the officials who supervise small loan licensees, of the states indicated, by Francis E. Wilcox, Statistician, Household Finance Corporation. Earnings and expenses per account and in relation to loan balances or assets were computed on the basis of monthly averages, when available, or the average of the beginning and ending of the year, or, last choice, year-end figures. 
TABLE I

\begin{tabular}{|c|c|c|c|c|c|c|}
\hline & \multicolumn{2}{|c|}{$\begin{array}{c}\text { Max. } \$ 300 \\
\text { No other Law }\end{array}$} & \multicolumn{2}{|c|}{$\begin{array}{c}\text { Max. } \$ 3001940 \\
\text { and } \$ 5001951 \\
\text { No other Law }\end{array}$} & \multirow{2}{*}{$\begin{array}{c}\text { No Max. } \\
1940 \\
\$ 1000 \\
1951 \\
\text { No other } \\
\text { Law } \\
\text { Ohio }\end{array}$} & \multirow{2}{*}{$\begin{array}{c}\text { Max. } \$ 300 \\
\text { Larger } \\
\text { Loans } \\
\text { other } \\
\text { Law }\end{array}$} \\
\hline & Iowa & Va. & Ill. & N.Y. & & \\
\hline 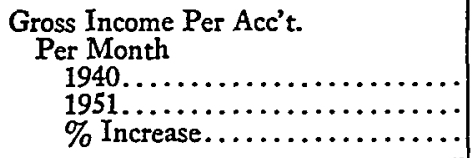 & $\begin{array}{l}\$ 3.04 \\
\$ 4.37 \\
43.8 \%\end{array}$ & $\begin{array}{l}\$ 2.80 \\
\$ 3.57 \\
27.5 \%\end{array}$ & $\begin{array}{l}\$ 2.90 \\
\$ 4.92 \\
69.7 \%\end{array}$ & $\begin{array}{l}\$ 3.22 \\
\$ 4.40 \\
36.6 \%\end{array}$ & $\begin{array}{l}\$ 3.31 \\
\$ 5.58 \\
68.6 \%\end{array}$ & $\begin{array}{l}\$ 2.70 \\
\$ 3.29 \\
21.9 \%\end{array}$ \\
\hline 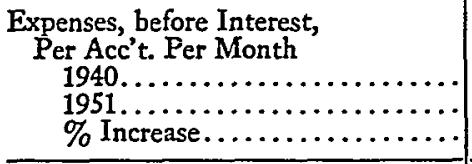 & $\begin{array}{l}\$ 2.11 \\
\$ 3.35 \\
58.8 \% \\
\end{array}$ & $\begin{array}{l}\$ 1.83 \\
\$ 2.61 \\
42.6 \%\end{array}$ & $\begin{array}{l}\$ 2.00 \\
\$ 3.64 \\
82 . \%\end{array}$ & $\begin{array}{l}\$ 2.09 \\
\$ 3.12 \\
49.3 \%\end{array}$ & $\begin{array}{l}\$ 2.20 \\
\$ 3.96 \\
80 . \%\end{array}$ & $\begin{array}{l}\$ 1.76 \\
\$ 2.53 \\
43.8 \%\end{array}$ \\
\hline 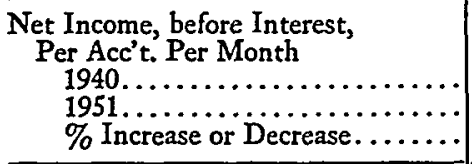 & $\begin{array}{l}\$ 0.93 \\
\$ 1.02 \\
9.7 \%\end{array}$ & $\begin{array}{r}\$ 0.97 \\
\$ 0.96 \\
-1.0 \%\end{array}$ & $\begin{array}{l}\$ 0.90 \\
\$ 1.29 \\
43.3 \%\end{array}$ & $\begin{array}{l}\$ 1.12 \\
\$ 1.28 \\
14.3 \%\end{array}$ & $\begin{array}{l}\$ 1.11 \\
\$ 1.62 \\
45.9 \%\end{array}$ & $\begin{array}{r}\$ 0.94 \\
\$ 0.77 \\
-18.1 \%\end{array}$ \\
\hline 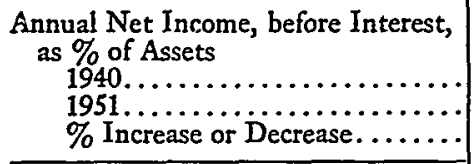 & $\begin{array}{r}8.92 \% \\
6.52 \% \\
-26.9 \%\end{array}$ & $\begin{array}{r}11.12 \% \\
6.94 \% \\
-37.6 \%\end{array}$ & $\begin{array}{r}8.62 \% \\
6.57 \% \\
-23.8 \%\end{array}$ & $\begin{array}{r}8.82 \% \\
6.12 \% \\
-30.6 \%\end{array}$ & $\begin{array}{r}6.93 \% \\
5.62 \% \\
-18.9 \%\end{array}$ & $\begin{array}{r}8.13 \% \\
5.28 \% \\
-35.1 \% \\
\end{array}$ \\
\hline 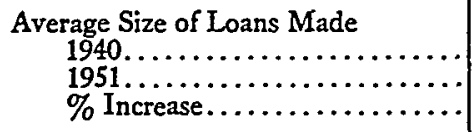 & $\begin{array}{l}\$ 135 \\
\$ 205 \\
51.9 \%\end{array}$ & $\begin{array}{l}\$ 110 \\
\$ 201 \\
82.7 \%\end{array}$ & $\begin{array}{l}\$ 133 \\
\$ 253 \\
90.2 \%\end{array}$ & $\begin{array}{l}\$ 158 \\
\$ 295 \\
86.7 \%\end{array}$ & $\begin{array}{l}\$ 182 \\
\$ 362 \\
98.9 \%\end{array}$ & $\begin{array}{l}\$ 151 \\
\$ 198 \\
31.1 \%\end{array}$ \\
\hline 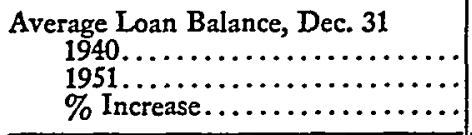 & $\begin{array}{l}\$ 109 \\
\$ 168 \\
54.1 \%\end{array}$ & $\begin{array}{l}\$ 92 \\
\$ 161 \\
75.0 \%\end{array}$ & $\begin{array}{l}\$ 110 \\
\$ 210 \\
90.9 \%\end{array}$ & $\begin{array}{l}\$ 127 \\
\$ 234 \\
84.3 \%\end{array}$ & $\begin{array}{l}\$ 154 \\
\$ 297 \\
92.9 \%\end{array}$ & $\begin{array}{l}\$ 120 \\
\$ 157 \\
30.8 \%\end{array}$ \\
\hline 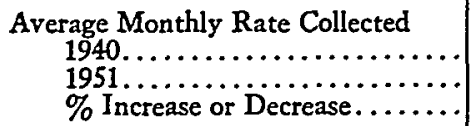 & $\begin{array}{r}2.68 \% \\
-2.61 \% \\
-2.6 \%\end{array}$ & $\begin{array}{r}3.17 \% \\
2.43 \% \\
-23.3 \%\end{array}$ & $\begin{array}{r}2.57 \% \\
2.40 \% \\
-6.6 \%\end{array}$ & $\begin{array}{r}2.60 \% \\
1.96 \% \\
-24.6 \%\end{array}$ & $\begin{array}{r}2.16 \% \\
1.91 \% \\
-11.6 \%\end{array}$ & $\begin{array}{l}2.23 \% \\
-2.11 \% \\
-5.4 \%\end{array}$ \\
\hline
\end{tabular}

Increased loan limits were accompanied by sharply reduced rates on the larger portion of the increased loan. The monthly rate on such large balances is $1 / 2$ per cent in Connecticut, New Jersey, and New York, 3/4 per cent in Michigan and Nebraska, I per cent in Illinois, Nevada, New Mexico, Pennsylvania, and Wyoming, and $I_{-1}^{-1 / 2}$ per cent in Maine. In Illinois, Michigan, and Nevada there was a reduction also in the maximum charge on loan balances of less than $\$ 300$.

California in $x 949$ extended its 2 per cent maximum rate between \$roo and $\$ 300$ up to $\$ 500$ and imposed a $5 / 6$ per cent per month limit on the larger balances. 57 Indiana in I95I extended its $1-1 / 2$ per cent rate on loan balances between $\$ 150$ and

${ }^{87}$ Cat. Stat. \& Code Amdts. 1949, c. 1033. 
$\$ 300$ up to $\$ 500 .^{58}$ South Dakota in 1953 set a maximum of $3 / 4$ per cent per month on balances between $\$ 300$ and $\$ 2,500 .^{58}$

As a result of the reduction in rates of profit, many lenders who previously charged less than the legal limits have increased their rates toward the maximum with consequent reduction of competition between lenders. Resistance to further lowering of legal maximum rates and support for rate increases are increasing. Evasive devices to increase charges are on the increase, notably the forced tie-in sale of credit life and disability insurance.

\section{$\mathrm{V}$ \\ Convenience and Advantage Provision}

The most complex administrative problem which has arisen since 1940 concerns the determination of whether a small loan license "will promote the convenience and advantage of the community in which the business of the applicant is to be conducted." This provision originated in the fifth draft of USLL in I932 and is now found in slightly varied forms in the small loan laws of 23 states. $^{60}$ Its main purpose was to prevent over lending and the attendant evils resulting from excessive competition. ${ }^{61}$ There is a strong difference of opinion among informed persons as to whether this provision has accomplished its purpose and whether it is a desirable addition to the USLL. It has been applied with varying degrees of strictness in different states and sometimes at different times within the same state.

The meaning of "convenience and advantage," and to a lesser extent of "community," as applied to specific factual situations has been before numerous licensing officials and several courts. These terms provide sufficiently definite standards to satisfy constitutional restrictions on delegation of legislative power, the requirement having been uniformly sustained against constitutional attack. ${ }^{62} \mathrm{New}$ judicial interpretations must occur, however, before "the convenience and advantage of the community" will acquire a predictable meaning. Decisions involving comparable restrictions in the banking, public utility, and radio field are only moderately helpful as the factual situations are so different. ${ }^{63}$

\footnotetext{
8I Ind. Laws I95I, c. 86.

${ }^{50}$ S.D. Laws I953, S.B. 349.

${ }^{\circ}$ For states having the provision, see note I2 supra. In Massachusetts the administrator's regulations attempt to impose a convenience and advantage requirement. The provision was omitted from the Model Consumer Finance Act.

${ }^{01}$ Sixth Draft of USLL, n. 14; Sullivan, Administration of a Regulatory Small Loan Law, 8 LAw \& Contemp. Prob. I46, I48 (I94I); Household Finance Corp. v. Gaffney, 2o N.J. Super. 394, 90 A. 2d 85 (1952), aff'd, II N. J. 576, 95 A. 2d 4 I2 (1953).

'Kelleher v. Minshull, II Wash. 2d 380, II9 P. 2d 302 (I94I); Family Finance Corp. v. Gaffney, II N.J. 565, 95 A. 2d 407 (r953); Family Finance Corp. v. Gough, Io N.J. Super. 13, 76 A. 2 d 82 (1950); Motors Acceptance Corp. v. McLain, I54 Neb. 354, 47 N. W. 2d 919 (r95I); Equitable Loan Socicty, Inc. v. Bell, 339 Pa. 449, I4 A. 2 d 316 (I940), app. dis., 31 I U. S. 621 (1940).

${ }^{83}$ See Hall, Certificates of Convenience and Necessity, 28 MrCH. L. Rev. 107 (1929), 276 (1930); Note, Radio Regulation and Freedom of the Air, 54 Harv. L. REv. 1220 (194r); Bank of Italy v. Johnson, 200 Cal. I, 25I P. 784 (I926); Weer v. Page, I55 Md. 86, I4I A. 518 (1928); State ex rel. Dybdal v. State Securities Commission, I45 Minn. 221, I76 N.W. 759 (1920). For comment as to need for administrative licensing standards under Michigan small loan law, see Staff Report to the Michigan Joint Legislative Committee on Reorganization of State Government, I953, p. 28-II-47.
} 
When supported by adequate findings and proof, administrative denials of licenses under this provision have been upheld by the courts, ${ }^{64}$ but the opinions have neither identified the controlling factors nor indicated the weight to be given to each. The administrative findings and conclusions do not settle on any criteria as decisive.

In New Jersey proceedings, ${ }^{65}$ the Commissioner has considered such factors as population, retail sales per licensee in the community compared to those throughout the state, whether a city is a trade center for outlying territory, the number of banks and credit unions making similar loans in the community, competition between licensees in other cities and licensees in the community, and whether existing licensees have sufficient capital and credit to meet the community's demand for consumer loans. ${ }^{68}$ A New Jersey decision indicates that the "community" is not necessarily the area within municipal boundaries. ${ }^{67}$

The New Jersey and Washington commissioners and courts have disregarded the fact that an applicant charged a lower rate than existing licensees. ${ }^{08}$ In contrast, the New York administrator gave weight to a stipulation providing for cancellation of the license if the applicant should increase its charge above 2 per cent per month, which was less than the maximum permitted rate, and was upheld by a trial court. $^{69}$

Provisions requiring a hearing have been interpreted and enforced in two cases. ${ }^{70}$ New Jersey courts have held that the licensing official must make findings of fact to support a denial. ${ }^{71}$ In Washington, where the Act provides for a trial de novo on appeal from a denial, the Supreme Court held that this was an unconstitutional delegation of non-judicial power to the courts. ${ }^{72}$

\section{VI}

\section{Credit Life and Disability Insurance}

The prohibition against extra charges in the small loan law is in such sweeping terms that it should be construed to prohibit credit insurance charges, except in a few states where they are specifically authorized.

o Motors Acceptance Corp. v. McLain, I54 Neb. 354, 47 N. W. 2d 919 (195r); Family Finance Corp. v. Gaffney, ix N.J. 565, 95 A. 2d 407 (1953); Household Finance Corp. v. Gaffney, ix N.J. 576, 95 A. 2d 412 (1953); Household Finance Corp. v. State, 40 Wash. 2d 45I, 244 P. 2d 260 (1952).

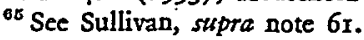

${ }^{86}$ Family Finance Corp. v. Gaffney, II N.J. 565, 95 A. 2d 407 (1953).

${ }^{67}$ Household Finance Corp. v. Gaffney, 20 N.J. Super. 394, go A. 2d 85 (1952), aff'd, II N.J. 576, 95 A. 2d 412 (1953). Apparently the New Jersey Commissioner has accepted this view. See findings summarized in Family Finance Corp. v. Gaffney, $x x$ N.J. 565, 95 A. $2 d 407$ (1953).

${ }^{68}$ Household Finance Corp. v. Gaffney, 20 N.J. Super. 394, 90 A. 2d 85 (I952), aff'd, II N.J. 576, 95 A. 2d 412 (1953); Household Finance Corp. v. State, 40 Wash. 2d 45I, 465, 244 P. 2d 260, 268 (1952).

${ }^{69}$ Personal Finance Co. of New York v. Lyon, x2I N.Y. S. 2d 72 (Sup. Ct., N.Y. Co. 1953).

${ }^{70}$ Deutsch v. Department of Insurance, 397 Ill. 218, 73 N. E. $2 d$ 304 (1947); Family Finance Corp. v. Gough, ro N.J. Super. 13, 76 A. 2d 82 (1950).

${ }^{71}$ Household Finance Corp. v. Gaffney, II N.J. 576, 95 A. 2d 4 12 (1953); Family Finance Corp. v. Gough, ro N. J. Super. I3, 76 A. $2 d 82$ (1950).

${ }^{22}$ Household Finance Corp. v. State, 40 Wash. 2d 451, 244 P. 2d 260 (x952); Lewis, Household Finance Case: Statutory Review of Discretionary Power to License, 28 WasH. L. REv. 146 (1953). 
The recent interest of licensees in obtaining extra profits from selling credit insurance is due to various factors, including: the entrance into the consumer finance business of lenders who had previously made loans only upon security and were not familiar with the philosophy of the USLL; the reduction in profit margins already mentioned; and the mushroom growth of small insurance companies specializing in insurance sold in connection with consumer credit transactions.

Insurance as security for necessitous small loans is foreign to the original concepts of the USLL. Most small loans to consumers are not secured, in the customary sense of the word. ${ }^{73}$ Originally only two types of security were commonly taken, mortgages on household goods and wage assignments. ${ }^{74}$ Such mortgages, usually unrecorded, were valuable only for psychological effect, ${ }^{75}$ and wage assignments merely assure delivery of part of the borrower's earnings which remain the primary source for repayment.

The practice of requiring or selling credit life, health and accident insurance began in areas of consumer credit which were not subject to the small loan law. The first litigation over insurance charges under small loan laws involved merely the licensee's right to require insurance on automobile security and did not involve his profiting from the sale of insurance. The hazardous nature of automobile security and the lack of profit to the lender made a strong case. Applying the reasoning by which extra charges incident to the furnishing of security have been sustained under general usury laws, several state courts resolved the issue in favor of the lender. ${ }^{78}$

Encouraged by these decisions applicable to insurance sold in good faith by third parties, some licensees started to sell credit life and disability insurance to their borrowers, profiting from the commissions in addition to the statutory charge. It was contended that credit insurance is necessary and that borrowers usually want it when offered. Both contentions disregard the fact that from $4^{\circ}$ per cent to over

${ }^{73}$ Seventh Draft of USLL $\$ 1, F$. W. RYaN, Usury AND Usury LAws 134, 135 (1924); Eskildson, The Small Loan Problem in Colorado, U. of Denver Rep. 9 (Dec. 1942). This concept and the need for greater charges than the general usury maximum to cover the greater risk are expressly recognized in some laws: Fla. Laws r925, c. IoI77, Preamble; Md. Laws r918, c. 88, Preamble; N. M. Strt. AnN. $\$ 50-1620$ (Supp. I95I); Nev. Comp. Laws 1943-1949 \$753. Also in court decisions: Davis Loan Co. v. Blanchard, 14 La. App. 671 , 129 So. 413 , teh. denied, 130 So. 472 (1930); Liberty Finance Co., Inc. v. Catterton, 16I Md. 650, 158 A. I6 (r932); Lackawanna Thrift \& Loan Corp. v. Kabatchnick, $145 \mathrm{~Pa}$. Super. 52, 20 A. $2 \mathrm{~d} 903$ (194I). See also Girard Investment Co. v. Commissioner of Int. Rev., I22 F. 2d 843 (3d Cir. 194I); Ex parte Fuller, I5 Cal. 2d 425, I02 P. 2d 32I (1940); Westville \& Hamden Loan Co. v. Pasqual, rog Conn. Iro, 145 A. 758 (1929).

"Robinson and Stearns, op. cit. supra note 46 , at 138 ; Young, Personal Finance Companies and Their Credit Practices 49 (Nat. Bur. of Econ, Res., 1940).

${ }^{75}$ Neifeld, The Personal Finance Business 153 , 156 (1933); Foster, The Personal Finance Business Under Regulation, 8 Law \& Contemp. PROB. 154, I68 (194I).

${ }^{70}$ Platz v. Lapinski, 263 Mich. 240, 248 N. W. 607 (I933); Auto Owners' Finance Co., Inc. v. Coleman, 89 N.H. 356, x99 A. 365 (r938); Maellaro v. Madison Finance Co., I30 N.J. L. 140, 31 A. $2 d 485$ (Sup. Ct. I943), aff'd, I3I N.J. L. I60, 35 A. 2d 714 (I944); Martorano v. Capital Finance Corp., 289 N.Y. 21,43 N. E. 2d 705, I43 A. L. R. I3I8 (1942). The lower New York courts had reached the contrary result in Martorano v. Capital Finance Corp., 263 App. Div. 79, 3I N.Y. S. $2 d 643$ (rst Dep't 194I), rev'd, 289 N.X. 21, 43 N. E. 2d 705, 143 A. L. R. 1318 (1942); Krulik v. Confidential Personal Loan Co., 176 N.Y. Misc. 138, 26 N.Y. S. $2 d 676$ (Sup. Ct. App. Term 194I). 
80 per cent of the premium is retained by the lender, directly or indirectly. Profiting from the sale of credit insurance in addition to the charges permitted by the small loan laws violates the cardinal principle of a single, all-inclusive maximum rate of charge. It opens the door to manipulations and devices. Whenever anything has been sold in connection with small loans, abuses have resulted. ${ }^{77}$ Like vitamin pills, life and disability insurance may be good for borrowers, but licensed lenders should no more be permitted to profit from tie-in sales of insurance than from tie-in sales of vitamin pills. ${ }^{78}$

Tie-in sales have always been a favorite device of loan sharks. Pipes, door mats, inkwells, and other articles of small value have been sold at high prices to obtain hidden profits. ${ }^{7 \theta}$ Such sales are unmanageable elements in relation to a definite and enforceable ceiling on the charges of consumer creditors. If an overall maximum charge cannot be defined and enforced, regulation breaks down.

In the last analysis, open and honest competition between consumer creditors of all types is the strongest hope of the consumer debtor. If a licensee may advertise I per cent a month and obtain 3 per cent by profits on tie-in sales, other licensees cannot compete except by similar methods; the debtor cannot select the lowest price, ${ }^{80}$ and the state cannot enforce a rate ceiling. A return to pre-rgi6 jungle tactics would seem inevitable.

It is a hopeful development that several of the larger licensee companies have commenced to provide their borrowers with the cheaper group credit life insurance, free of extra charge.

Strong pressure has been generated, however, for legislation authorizing lenders to sell such insurance. Small loan laws so amended include Louisiana (1952) ${ }^{81}$ and Nebraska (1953). ${ }^{82}$ The Missouri law (I95I) delegates the problem to the enforcement official, who by regulation permits the sale of decreasing term life insurance. The new South Dakota law (I953) permits lenders to sell credit insurance to borrowers of more than $\$ 300$. In New Mexico it is sold under implied authority of a I949 restrictive act..$^{83}$ In Colorado where credit insurance sales were tolerated for a time, the Governor vetoed a 1953 bill which would have permitted small loan licensees to sell credit life insurance.

\footnotetext{
${ }^{77}$ See Parish, Credit Life, Health and Accident Insurance and the Small Loan Industry, 6 N. M. Bus. 3 (College of Bus. Admin., U. of N.M., JunE, I953).

${ }^{78}$ An unlicensed lender was recently held to have violated the Michigan small loan law by tie-in sales of vitamin pills. People v. Coleman, 59 N. W. $2 d 276$ (Mich. Sup. Ct. 1953).

${ }^{70}$ See Willis v. Buchman, 199 So. 886 (Ala. App. 1940), rev'd on other grounds, 240 Ala. 386 , I99 So. 892 (r940); People v. Vanderpool, 114 P. 2d 608 (Cal. App. 194I), rev'd on osher grounds, 20 Cal. 2d 746, 128 P. 2d 513; People v. Silverberg, 33 N.Y. Cr. 46, 160 N.Y. S. 727 (1915), affd, 17r App. Div. 914, 155 N.Y. S. 1132 (1st Dep't 1915).

${ }^{80}$ Yntema, The Market for Consumer Credit: A Case in "Imperfect Competition," I96 ANwals 79 (March, 1938); Phelps, Monopolistic and Imperfect Competition in Consumer Loans, 8 Journal op Marketing 382 (1944).

${ }^{81}$ La. Acts 1952, No. I69. The Louisiana amendment nullified a 195I decision of the Louisiana Court of Appeals. Home Finance Co. v. Padgett, 54 So. 2d 815 (La. App. I95I).

82 Neb. Laws 1953, L. B. 280.

${ }^{83}$ N.M. L.aws 1949, c. 130, as amended by N.M. Laws 1953, S. B. 240.
} 
The only appellate court decision sustaining a charge for credit life insurance by a licensee under an orthodox small loan law was a test case on unrealistic facts pleaded by the lender and admitted by demurrer. ${ }^{84}$ When the validity of such a charge was squarely challenged in another state, it was held to violate the small loan law. ${ }^{85}$ In accord with this decision are opinions of the Colorado and Illinois Attorneys General. ${ }^{86}$ These rulings are supported by decisions involving tie-in sales of life insurance by lenders operating under general usury acts or other lending laws. ${ }^{87}$

\section{VII}

\section{Spectal Constitutional Problems}

Constitutional Interest Maxima. The constitutions of Arkansas, Oklahoma, Tennessee, and Texas limit interest charges to a rate of ro per cent per annum. As consumer lending cannot be profitable at this rate, these constitutional limitations prevent enactment of effective small loan laws. Various legislative attempts to evade or avoid these limitations have failed.

The Arkansas installment loan act of $195^{\mathrm{I}^{88}}$ purported to authorize certain expense and service charges in addition to ro per cent interest. The Arkansas Supreme Court held the authorization unconstitutional as an attempt to authorize interest charges exceeding the constitutional limit under various disguises. ${ }^{89}$ The act was later repealed..$^{90}$

The Tennessee small loan act ${ }^{91}$ originally attempted to permit an expense charge of 3 per cent per month in addition to lawful interest. This act was interpreted to limit rather than authorize expense charges and, as so interpreted, was held constitutional. $^{92}$

The Oklahoma small loan law ${ }^{93}$ authorizes, in addition to interest, an initial charge to cover costs of making the loan and monthly fees to cover carrying costs. This act has not yet been submitted to the Oklahoma Supreme Court.

Texas has two laws which purport to legalize charges in addition to interest.

94 Mills v. Parrott, 237 S. W. 2d 851 (Ky. 195I). The action was brought after another lender dismissed an appeal from a decision that charges for credit life insurance violated the Kentucky small loan law. Lewis v. Interstate Loan Corp., Jefferson Cir. Ct., Chan. Br., 2d Div., No. 305960 (I948).

${ }^{85}$ See note 81 supra.

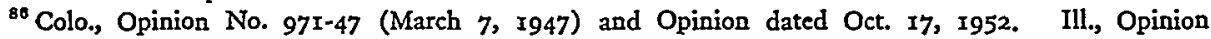
dated July 21, 1950.

${ }^{87}$ Strickler v. State Auto Finance Co., 220 Ark. 565, 249 S. W. 2d 307 (1952); Commonwealth ex rel. Grauman v. Continental Co., 275 Ky. 238, 121 S. W. $2 d 49$ (1938); Jernigan v. Loid Rainwater Co., I96 Ark. 251, I17 S. W. 2d I8 (1938); In re Graham, 22 F. Supp. 233 (W. D. Ky. 1938); Peebles v. State, 87 Ga. App. 649 , 75 S. E. 2d 35 (1953). There are decisions, however, sustaining the requirement of life insurance under usury laws when the circumstances showed that the requirement was bona fide. HuBACHER, op. cit. supra note 2 , at 168 .

${ }^{88}$ Ark. Acts I95I, No. 203.

so Winston v. Personal Finance Co. of Pine Bluff, Inc., 220 Ark. 580, 249 S. W. 2 d 355 (I952); Strickler v. State Auto Finance Co., 220 Ark. 565, 249 S. W. $2 d 307$ (I952).

${ }^{\circ 0}$ Ark. Acts 1953, No. 39 I.

${ }^{01}$ TENN. CODE ANN. $\$ \$ 6721-6743$ (Williams, 194I).

${ }^{92}$ Koen v. State, 162 Tenn. 573,39 S. W. $2 \mathrm{~d} 283$ (1930).

os OrLa. Stat. ANN. tit. 15, \$\$280.I-280.29 (Supp. I952). 
A I949 $\mathrm{act}^{94}$ would legalize the sale of credit life and disability insurance to consumer borrowers and the receipt of commissions by lenders. A I95 ${ }^{1}$ act $^{05}$ would authorize industrial loan corporations to collect expense charges and to make tie-in installment sales of their investment certificates to borrowers. The Texas Supreme Court has not yet determined their constitutionality, but each act has been upheld by a Court of Civil Appeals. The Texas Supreme Court has granted a writ of error from a curious decision on the $195^{1}$ act. $^{96}$

The legality of extra charges under any such law will be subject to challenge by the borrower in each transaction. ${ }^{.7}$ Even if specific charges should be sustained under such a law in an individual case or cases, it would not provide a sound basis for conducting a consumer finance business. ${ }^{98}$ It would seem that an effective solution of the loan shark problem in these four states must await amendment or repeal of their constitutional interest limitations.

Arkansas recently attempted to submit such an amendment to the voters, but their Supreme Court ordered it stricken from the ballot because of defects in form. ${ }^{90}$ The Texas Bar Association has recommended a constitutional amendment and the proposal has widespread support.

Until these constitutional road blocks to sound consumer finance legislation are swept away, the best that can be expected would be only partially effective laws based, in the last analysis, on sham or avoidance.

Missouri Constitutional Provision. A unique provision of the Missouri Constitution of $1945^{100}$ as interpreted by the Missouri Supreme Court, ${ }^{101}$ prohibits classification of lenders for the purpose of fixing maximum interest rates. In 1947 it was held to have repealed the prior small loan law. ${ }^{102}$ Missouri was thereafter without a consumer loan law until the enactment of new legislation in $195^{1 .}{ }^{103}$ This legislation consists of two acts which embody many of the basic principles of modern small loan regulation. It satisfies the constitutional requirement by making the maximum rate applicable to and available to all lenders.

ot Tex. Acts 1949, c. 491; ANn. Tex. Stat., Insurance Code, Art. 3.53 (Vernon, 1952).

${ }^{98}$ Tex. Acts 1951, c. 472; ANN. TEx. STAT. Art. 1524a-I (Supp. 1952).

${ }^{\circ}$ Steiner v. Community Finance \& Thrift Corp., 258 S. W. 2d 129, 134 (Tex. Civ. App. 1953): "The issues discussed hereinabove ... substantiate the opinion here expressed that in the absence of precedeat which is considered binding on the court, an examination of the statute and the entire transaction here in issue, impels the opinion that Art. I524a-I is mercly a cloak under which usurious interest is charged in violation of the Constitution of the State of Texas." The r949 act was sustained in Hatridge v. Home Life \& Accident Ins. Co., 246 S. W. $2 \mathrm{~d} 666$ (Tex. Civ. App. 195I).

${ }^{97}$ See Family Loan Co. v. Hickerson, I68 Tenn. 36, 73 S. W. 2d 694 (r934); Personal Finance Co. v. Hammack, I63 Tenn. 64I, 45 S. W. 2d 528 (I932); Golightly v. Hermitage Loan Co., I7I Tenn. 70, 100 S. W. $2 \mathrm{~d} 654$ (I937).

${ }^{98}$ Donaldson, Small Loan Legislation in Texas, 20 Tex. L. Rev. 186, 192 (1941): ". . . the lender would be constantly beset by the uncertainty of whether his expense charges were legal or illegal and whether his notes were fully collectable. No legitimate business can prosper or long continue under such a cloud."

${ }^{\circ}$ Bradley v. Hall, 220 Ark. 925, 25 I S. W. 2d 470 (I952).

${ }^{201}$ Household Finance Corp. v. Shaffner, 356 Mo. 808, 203 S. W. 2d 734 (1947).

${ }^{102}$ Ibid. 1952).

${ }^{103}$ Mo. Laws I95I, pp. 262, 875; ANN. Mo. STAT. $\$ \$ 367.100-367.200$, 408.100-408.220 (Vernon, 
One act amended the usury law to authorize certain charges exceeding the general 8 per cent maximum on loans of $\$ 400$ or less, with certain exceptions..$^{104}$ The authorized and the maximum rate is 2.218 per cent per month, subject to various regulatory provisions. The second act provides for the licensing and supervision of lenders engaged in the business of making unsecured loans and loans secured by personal property or wage assignments. It applies whether or not the lender's charges exceed the general usury maximum. Banks and other lenders supervised under different laws are exempted from the second act. Special features of the combined legislation include permission to charge the small loan rate on the $\$ 400$ portion of a larger loan and to contract for charges either as a percentage interest rate or as a precomputed dollar amount. These and other unusual features are designed to make the maximum rate applicable to and the authorized rate available to all classes of lenders including banks and industrial loan companies.

\section{VIII}

\section{Trend Toward A Code}

The Missouri r95I legislation, though forced into a peculiar form by constitutional limitations, is the first permissive consumer loan law with a comprehensive plan of regulation which embraces all types of lenders without regard to institutional background, size of loan, method of procedure, or similar characteristics. The practical working out of this legislation is still to be demonstrated, but, as an attempt to grant the same permissions with the same limitations to all consumer lenders, it is a bold step to be carefully observed and considered.

There is a discernible trend in legislation toward a uniform system of regulations applicable to consumer creditors and notably to all types of consumer lenders. The development is not so much toward identical regulations as it is toward an integrated plan of regulation in which each credit agency is regulated in accordance with its own peculiarities but in harmony with the regulations of other agencies.

This process is beginning to reduce the differences between the earlier rigid and the later lax statutes. Small loan companies were originally subjected to overly strict regulation in the early experimental period. Some of the later restrictions have subsequently been made unnecessary by the tremendous growth of consumer lending by other agencies. Later when banks and other new types of consumer lenders sought enabling legislation, the increased public understanding of installment credit had reduced the burden of obtaining legislative approval. Hence enabling legislation for these agencies contained a minimum of, or no, regulation to protect the borrower.

In I944, Professor George C. Bogert noted the need for more uniform legislation in this field. ${ }^{105}$ In I949, this author noted a drift toward a consumer credit code. ${ }^{108}$ Since I949, a further drift has occurred. Repeal of the bond requirement in the

106 Mo. Laws 195x, p. 875.

${ }^{105}$ Bogert, supra note 40.

${ }^{100}$ Hubachek, supra note 40. 
New York Small Loan Law, ${ }^{10 \tau}$ exemption of inadvertent overcharges from the penalties for excessive charges, ${ }^{108}$ administrative or statutory permissions to engage in other businesses, and the increase in small loan size limits are either relaxations of small loan laws or changes in the direction of more uniform treatment of consumer lenders. In contrast, new legislation applying to other installment creditors has either tightened existing laws or imposed some degree of regulation for the first time. The New Jersey Bank Installment Loan Law was strengthened in 1950, and Indiana (195r) and South Dakota (1953) enacted bank installment loan laws which, though defective, authorize charges exceeding the usury law and provide some protection to the borrower. ${ }^{109}$ California (I949) added a refund requirement to its automobile sales finance law. ${ }^{110}$ Connecticut (1949) tightened its sales finance law in material respects. ${ }^{111}$ Michigan (1950) replaced its rudimentary automobile sales finance act with a comprehensive regulatory law. ${ }^{112}$ Maine (195I) added to a fragmentary automobile finance law requirements as to disclosure of finance, insurance, and other charges and as to licensing. ${ }^{113}$ Wisconsin (I953) added rate regulation to its 1935 automobile sales finance law. ${ }^{114}$ Ohio (I949), Colorado (195r), and Nevada and Utah (I953) enacted sales finance legislation for the first time.110 The 195I Missouri legislation has already been mentioned. Fourteen additional states have enacted varying forms of an act prohibiting lenders and finance companies from requiring customers to buy insurance from a designated agent. ${ }^{116}$

\section{IX}

\section{Regulation W-Economic Considerations}

Regulation W was another step in the direction of a code of regulations embracing all consumer credit agencies. That action was on the economic front and is not cited to prove what could be done by a state legislature with a code of regulations intended largely to protect the debtor. Nevertheless, Regulation W disregarded institutional differences among the sources of consumer credit and many of its provisions were identical for all consumer creditors.

Regulation $\mathrm{W}$ was first intended as a war measure to dampen the demand for consumers' durable goods and thus reduce the pressure on scarce materials and services. After the national emergency, the Regulation was reimposed on the theory that consumer credit accentuates booms and retards recovery from depressions. ${ }^{117}$

${ }^{107}$ N. Y. Laws 1953, c. $573, \$ 2$.

${ }^{208}$ Twelve states now have such an exemption: Cal, Colo., Conn., Ill., Mo., Neb., Nev., N.M., Ohio, S.D., Utah, Va.

100 N.J. Laws 1950, c. 311; Ind. Acts I951, c. I59; S.D. Laws I953, c. 15.

${ }^{120}$ Caz. Stat. \& Code AMds. 1949, c. 1594. ${ }_{111}$ Conn. Laws 1949, Pub. Acts 281, 297.

${ }_{112}$ Mich. Pub. Acts 1950 (Ex. Sess.) No. 27. ${ }^{118}$ Me. Laws 1951, c. 361.

116 Wis. Laws 1953, c. 302.

${ }^{115} 123$ Ohio Laws 77 (1949); Colo. Laws 1951, c. 81; Nev. Laws 1953, S.B. 205; Utah Laws I953, c. 24 .

${ }^{120}$ Cal., Conn., Fla., Ga., Ky., La., Me., Mass., N.H., Ohio, Pa., Tenn., Va., Wis. Previously Mich., N.J., and N.Y. had enacted such laws. For citations to and reprints of these laws, as of I952, see BARRETT, op. cit. suprit note 4 .

${ }^{117} 62$ Stat. i29i; R. P. Shay, Regulation W: Experiment in Credit Control (University of 
Some believe that the control of consumer credit will assist in minimizing economic fluctuations, but others believe that the volume of consumer credit reflects rather than affects the national economy.

The Regulation came and went three times. A mass of figures was accumulated concerning conditions during and after each of these periods. What they prove, if anything, is the subject of a dispute in which this article will not participate. Certain statistics, however, cast a reasonably clear light on some of the characteristics of the different kinds of consumer credit and hence are appropriate for this discussion.

Table $\mathrm{II}^{118}$ recapitulates figures issued by the Federal Reserve Board showing the amounts of installment sale credit and of loans under small loan laws during the three periods when regulation was in force.

\section{TABLE II}

\section{Fluctuation of Installment Sale Credit and Smali Loan Law} OUtSTANDings, UnDER Regulation W (In millions of dollars)

\begin{tabular}{|c|c|c|}
\hline & $\begin{array}{c}\text { Total Sale } \\
\text { Credit }\end{array}$ & $\begin{array}{l}\text { Small } \\
\text { Loan Law } \\
\text { Outstandings }\end{array}$ \\
\hline 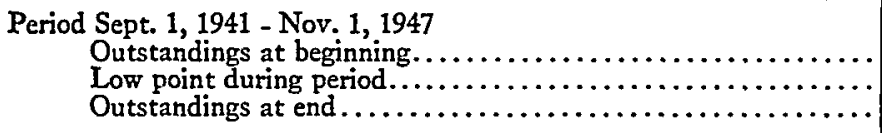 & $\begin{array}{r}\$ 4,742 \\
1,047 \\
3,521\end{array}$ & $\begin{array}{r}\$ 525 \\
342 \\
654\end{array}$ \\
\hline 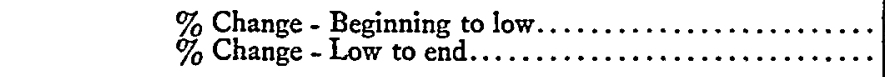 & $\begin{array}{l}-77.9 \% \\
+236.3 \%\end{array}$ & $\begin{array}{l}-34.9 \% \\
+91.2 \%\end{array}$ \\
\hline $\begin{array}{l}\text { Period Sept. } 20,1948 \text { - June } 30,1949 \\
\text { Outstandings at beginning } \ldots \ldots \ldots \ldots \ldots \ldots \ldots \ldots \ldots \ldots \ldots \ldots \ldots \ldots \ldots \ldots \ldots \ldots \ldots \ldots \ldots\end{array}$ & $\begin{array}{r}\$ 5,530 \\
6,612\end{array}$ & $\begin{array}{r}\$ 807 \\
866\end{array}$ \\
\hline 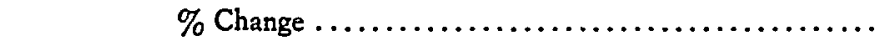 & $+19.6 \%$ & $+7.3 \%$ \\
\hline 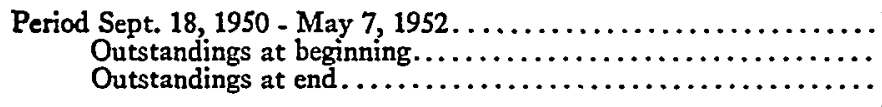 & $\begin{array}{r}\$ 10,605 \\
10,239\end{array}$ & $\begin{array}{r}\$ 1,040 \\
1,333\end{array}$ \\
\hline$\%$ Change.. & $-3.5 \%$ & $+28.2 \%$ \\
\hline
\end{tabular}

Maine Studies, Second Series, No. 67) i6i (U. of ME. Bull., April r953). See Nugent, op. cit. supra note 17.

${ }^{128}$ Compiled from 39 Fed. Res. Bulz. 336-354 (April, I953), and from Consumer Finance Conspanies Loans Outstanding (mimeo. release of Div. of Res., Fed. Res. Bd., as of May I953). For brevity, the dates of some of the above figures have been approximated. Federal Reserve Board figures for consumer credit have been gathered and issued from time to time on varying bases and with varying explanations and retroactive adjustments. The author assumes no responsibility for the above figures beyond stating his belief that, on averages and in general, they reflect the facts they purport to set forth. Installment sale credit as used in this table is the total of the amounts of "automobile paper" and "other consumer goods paper," as revised by the Federal Reserve Board in its April Bulletin. These amounts include loans for the purpose of purchasing goods and are larger than the amounts previously published which were restricted to credit originated by retail dealers. 
The volume of credit at different times was affected by important factors in addition to Regulation W. ${ }^{110}$ The fact that sale credit increased after V-J Day and during the second period while Regulation $W$ was in force points toward the absence of consumers' durables during World War II as an important cause of the large decline in sales finance credit during the first Regulation $W$ period. In the case of consumer loans, it seems likely that their decline during the first period was due in large measure to increased income from full employment and the lack of spending opportunities, because during both the second and third Regulation W periods the volume of such loans increased greatly notwithstanding the Regulation.

The table also demonstrates that sales finance credit is much more volatile than loan credit. It shrank to 22 per cent of its previous volume during the war and was almost ten times its low point by the end of the third period. In contrast, small loans only decreased to 65 per cent of their previous volume and by the end of the third period they were less than four times their low. As small loans are made principally for needs-expenses which cannot be avoided-their volume cannor be greatly affected by mere legal fiat. As long as loans for family needs are available from legal sources they will be obtained there and, if that source is cut off, the demand will "go underground" and be supplied there. That is the essence of combating the loan shark.

Notwithstanding the growth of lending under small loan laws, the volume of consumer loans by licensees is now dwarfed by that of commercial banks and is less than the aggregate of the other types of consumer lenders. Relative sizes and rates of growth since 1940 are indicated by Table $\mathrm{III}^{120}$

\section{TABLE III}

\section{CONSUMER Installment LoAN OUtstandings 1940-1952}

(In millions of dollars)

\begin{tabular}{c|c|c|c|c|c|c|c}
\hline $\begin{array}{c}\text { End of } \\
\text { Year }\end{array}$ & Total & $\begin{array}{c}\text { Licensee } \\
\text { out- } \\
\text { standings }\end{array}$ & $\begin{array}{c}\text { Commercial } \\
\text { banks }\end{array}$ & $\begin{array}{c}\text { Industrial } \\
\text { banks and } \\
\text { loan } \\
\text { companies }\end{array}$ & $\begin{array}{c}\text { Credit } \\
\text { unions }\end{array}$ & $\begin{array}{c}\text { Miscel- } \\
\text { laneous } \\
\text { lenders }\end{array}$ & $\begin{array}{c}\text { Repair \& } \\
\text { moderniza- } \\
\text { tion loans }\end{array}$ \\
\hline $1940 \ldots \ldots$ & 1,967 & 498 & 692 & 236 & 174 & 99 & 268 \\
$1941 \ldots \ldots$. & 2,143 & 531 & 784 & 241 & 200 & 102 & 285 \\
$1942 \ldots \ldots$ & 1,431 & 417 & 426 & 161 & 130 & 91 & 206 \\
$1945 \ldots \ldots$. & 1,422 & 439 & 477 & 146 & 103 & 93 & 164 \\
$1946 \ldots \ldots$ & 2,352 & 597 & 956 & 215 & 153 & 109 & 322 \\
$1947 \ldots \ldots$. & 3,348 & 701 & 1,435 & 300 & 225 & 119 & 568 \\
$1948 \ldots \ldots$ & 4,072 & 817 & 1,709 & 364 & 312 & 131 & 739 \\
$1950 \ldots \ldots$ & 4,650 & 929 & 1,951 & 425 & 402 & 142 & 801 \\
$1951 \ldots \ldots$ & 5,555 & 1,084 & 2,431 & 494 & 525 & 157 & 864 \\
$1952 \ldots \ldots$ & 7,964 & 1,268 & 2,510 & 530 & 542 & 176 & 938 \\
\hline
\end{tabular}

${ }^{110}$ See SHaY, op. cit. supra note II7.

${ }^{120}$ Source: 39 FED. REs. BuLl. 276 (March, I953). The author has combined the figures for industrial banks and industrial loan companies. The Federal Reserve Bulletins for April, 1953, and thereafter contain revised statistics which do not break down installment loan outstandings by types of lenders or show separately the outstandings under small loan laws. Therefore, the figures in this table are taken from the March, I953, Bulletin. See note II 8 supra. 


\section{$\mathrm{X}$}

\section{The Present Situation}

From Igr6 through I930 the regulated small loan business fought for survival against loan sharks and public prejudice. Loan sharks sought to preserve their business by destroying the small loan laws. Their attack was three-pronged: challenge the constitutionality of the laws; obtain their repeal; emasculate them by reducing the permitted rate of charge to an unprofitable level.

Under attack on their constitutionality, small loan laws have always been sustained when drafted in accordance with constitutional title requirements. The last major attack was on the Washington law (I94I) and in sustaining it the court cited the many prior decisions holding small loan laws constitutional. This decision seems finally to have settled the constitutional questions. ${ }^{121}$

Attempts to obtain repeal of small loan laws have uniformly failed. No state legislature has ever repealed an effective small loan law without enacting another to take its place.

Attacks on rates have met with some success, as in Georgia where the small loan law is now ineffective because the maximum rate was reduced to $1 \frac{1}{2}$ per cent per month in $1935 .{ }^{122}$ In other states where the rate was reduced, as in New Jersey in I929 and Virginia in 1942, it was later raised to a workable level after experience had demonstrated that the reduction was too drastic. ${ }^{123}$ During recent years the occasional attempts to reduce the permitted rates to an unprofitable level have received little support.

During the last fifteen years the consumer credit business has progressed toward maturity. Most of the banks of the nation had entered the business and Regulation $\mathrm{W}$ had dealt with it as a necessary and vital economic factor so that consumer lending was fully accepted. The sheer weight of the amounts of money involved demonstrated its substantial influence on the economy. Understanding and acceptance are shown by the fact that securities of sales finance and small loan companies are listed on the nation's stock exchanges and held in large amounts by insurance companies, pension funds, and other public institutions. The accessibility of capital at competitive rates has, of course, helped to hold down the charges to borrowers.

With the burgeoning out of consumer credit generally, the licensed small loan business has become only a segment of a giant business. The authorized charges of licensed lenders no longer stand out as exceptions to the usury laws, for many similar exceptions have been made for other branches of the business. The public has realized the necessity of higher charges for retail consumer credit than for wholesale business credit, just as it accepts the higher price of coal by the basket over carload prices.

121 Kelleher v. Minshull, II Wash. 2d 380, II9 P. 2d 302 (I94I).

${ }^{122} \mathrm{Ga}$. Acts 1935, No. 285 .

${ }^{123}$ N. J. Laws 1929, c. 293 , Laws 1932, c. 62; Va. Acts 1942, c. 107, Acts 1944, c. 370 . See Nugent, Three Experiments with Small-Loan Interest Rates, 12 HARv. Bus. Rev. 35 (I933). 
The public has tended to regard all forms of consumer credit as a single industry or force. This concept has its dangers. It tends to obscure the special function of the small loan laws-extending cash credit to wage earners to meet their needs. It is to be hoped that the public and the legislatures will not overlook this special function and become less sensitive to the need for firm regulation and an adequate rate in this segment of consumer credit.

The ready public acceptance of sales financing with its high costs is not difficult to trace. It stems largely from the primary association with the automobile industry. In view of the direct relationship between the sales of automobiles and the employment of large numbers in the industry, the public has not been overly critical of the method of financing sales. Since the goodwill of customers was at stake, manufacturers have generally exerted a constructive influence on the practices of controlled or associated finance companies, ${ }^{124}$ but competition has worked imperfectly in that segment of consumer credit.

The expansion of the consumer credit business in volume, number of sources, and area of social impact has brought new problems of regulation. Clashes between the different types of consumer creditors and the inconsistencies between regulatory laws will continue to plague the business and the administrative officials and also the public. To the extent that regulatory or enabling laws give one segment a competitive advantage, there will be a continuing demand for equal treatment by those who feel discriminated against. Since the legality of all consumer lending is based on exceptions to the usury laws, in states having them, consumer creditors may still have to fight for existence-not only against outlaw creditors but against their competitors doing business under other less restrictive laws.

There is general recognition that consumer credit preforms two indispensable functions: financing family emergencies, which enables our people to cope with temporary financial difficulties, and financing the purchase of consumers' goods, without which it would be impossible to create an adequate market to sustain mass production, low unit costs, and prices within the average family budget. With all its halting and groping the period since $194^{\circ}$ has made reasonably good progress toward a rational scheme of regulation which will put each segment of the business in its proper niche and assign to each the privileges and restrictions which it deserves-all in the public interest.

That the small loan law is the effective method of eliminating the loan shark has been abundantly proved. By it more than thirty states have been largely purged of high-rate, illegal lending. The public task remaining in that direction is to enact approved new laws in unregulated states and bring the present laws up to date. In so far as pioneer thinking is concerned, the new problem is to regulate in the public interest the diverse, legitimate, business interests which now provide this country with some nineteen billion dollars of consumer credit, of which only about one and one-half billion dollars is provided under small loan laws.

${ }^{124}$ Nugent, op. cit. stipra note 17 , at 96 . 